\title{
Spiritualitas Kristen sebagai Dasar Implementasi HAM bagi Kaum Marginal
}

\author{
S. Sujatmoko ${ }^{1}$, Yehuda Indra Gunawan ${ }^{2}$, Andri $^{3}$ \\ ${ }^{1,2,3}$ Sekolah Tinggi Teologi Ekumene Jakarta, Indonesia \\ stefanussujatmoko7@gmail.com
}

\begin{abstract}
Cases of violence and discrimination against marginalized people are a condition that still often occurs in our society. In this situation, the role of spirituality becomes something fundamental in helping this social challenge, as well as with Christian spirituality, how Christians can apply human rights in this issue. The discussion in this article uses qualitative research with a literature review approach. The results of the study show that mature Christian spirituality through the source, namely the Lord Jesus, is manifested by the work of the Holy Spirit to be able to understand and interpret every teaching of God's Word, then it is applied in behavior and actions. The values of Christian spirituality in respecting God, respect for others, justice and love are the basic human rights for church members against the marginalized. Christian spirituality must touch the church, family, and school segments to continue to form church members so that they have mature Christian spirituality so that they are able to apply it to the marginalized.
\end{abstract}

Keywords: Christian spirituality; human rights; marginal people

\begin{abstract}
Abstrak: Kasus kekerasan dan diskriminasi kepada kaum marginal merupakan sebuah keadaan yang masih kerap terjadi di masyarakat kita. Dalam situasi ini, peran spiritulaitas menjadi sesuatu yang fundamental dalam membantu tantangan sosial ini, demikian juga dengan spiritualitas orang Kristen, bagaimana orang Kristen dapat mengaplikasikan HAM dalam persoalan itu. Pembahasan dalam artikel ini menggunakan penelitian kualitatif dengan pendekatan studi pustaka atau literture review. Hasil dari penelitian menunjukan bahwa spiritualitas Kristen yang matang melalui sumber yaitu Tuhan Yesus yang diwujudkan dengan karya Roh Kudus untuk dapat memahami dan menginterpretasikan setiap penagajaran Firman Tuhan, kemudian di aplikasikan dalam perilaku dan tindakan. Nilai spiritualitas Kristen dalam menghargai Allah, menghargai sesama, keadilan dan kasih menjadi dasar HAM bagi warga gereja terhadap kaum marginal. Spiritualitas Kristen harus menyentuh segmen gereja, keluarga dan sekolah untuk terus membentuk warga gereja supaya memiliki spiritualitas Kristen yang matang sehingga mampu mengaplikasikannya kepada kaum marginal.
\end{abstract}

Kata Kunci: HAM; kaum marginal; spiritualitas Kristen

\section{Pendahuluan}

Kaum marginal merupakan kelompok masyarakat yang di simbolkan dengan kelompok masyarakat yang lemah, papa dan rentan dengan kekerasan dan diskriminsai. Kondisi kaum marginal menjadi semakin terjepit dan kritis saat diperhadapkan dengan situasi pandemi Covid 19 yang melanda hampir seluruh dunia. Di Indonesia sendiri pandemi Covid 19 memporakporandakan seluruh segmen kehidupan manusia, mulai dari kesehatan, pendidikan, kesenian, dunia usaha, dan yang paling terasa di semua lapisan masyarakat adalah adanya dampak ekonomi. Situasi kaum marginal menjadi mulai terasa dengan diberlakukannya PSBB (Pemba- 
tasan Sosial Berskala Besar), kemudian diubah menjadi peraturan PPKM (Pemberlakuan Pembatasan Kegiatan Masyarakat) yang memberi dampak kepada kesulitan menjalankan usaha, bekerja sehingga berdampak pada kehidupan ekonomi masyarakat Indonesia. Hal ini tentunya baerdampak besar juga terhadap kaum marginal. Sebuah survei yang dilakukan oleh Lembaga Demografi Fakultas Ekonomi dan Bisnis Universitas Indonesia pada tahun 2020 lalu, menyebutkan bahwa kelompok marginal yaitu: penduduk prasejahtera, perempuan dan penyandang disabilitas sangat rentan dalam menghadapi pandemi Covid 19 yang terjadi di negara Indonesia. Data tersebut dapat di lihat dari gambar di bawah ini'

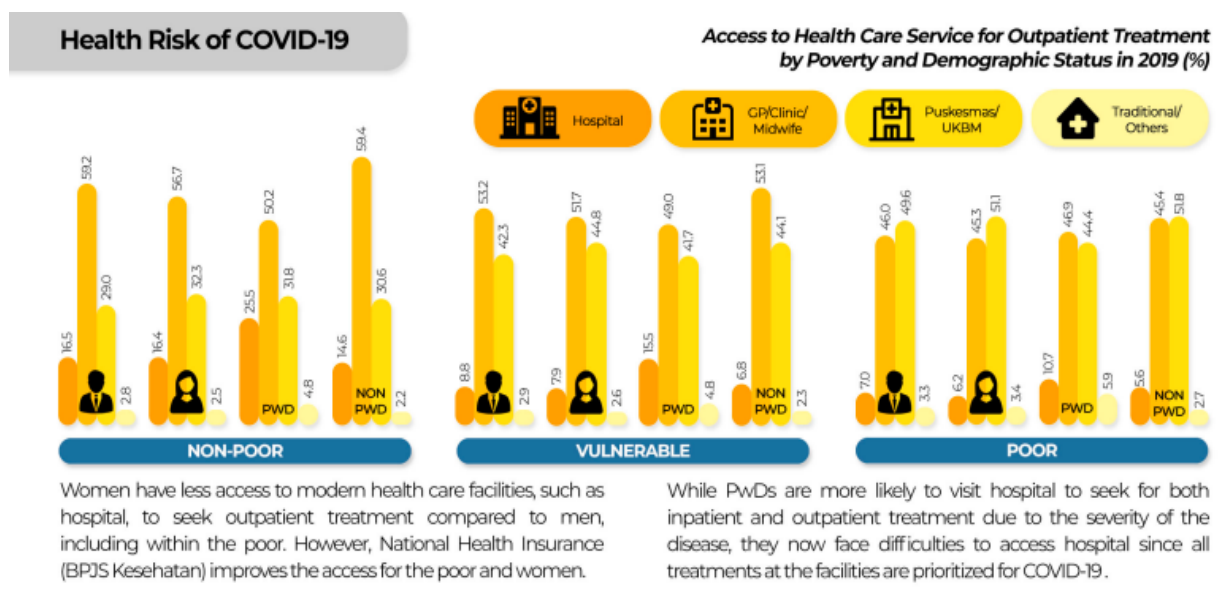

\section{Gambar 1: Survei Lembaga Demografi Fakultas Ekonomi dan Bisnis Universitas Indonesia}

Temuan serupa juga di sampaikan oleh Program LeaN On, sebuah inisiatif oleh Badan Nasional Penanggulangan Bencana (BNPB) dan INVEST DM, Peneliti utama Survei Endline LeaN On dari CIRCLE Indonesia, Isma Novitasari Yusadiredja, berkata, pandemi yg telah menimbulkan akibat yang sangat besar pada Indonesia telah mendorong 1,3 juta orang ke dalam kemiskinan, kelompok ini menjadi masyarakat yang mengalami marjinalisasi, terutama yang menghadapi banyak sekali diskriminasi, akan menjadi lebih rentan dalam keadaan bencana pandemi seperti sekarang ini. $^{2}$

Berdasarkan data survei tersebut, menunjukan bahwa kelompok marginal di masa pandemi Covid-19 mengalami peningkatan yang sangat signifikan, hal ini tentunya seiring dengan rentannya kaum marginal dengan diskriminasi dan kekerasan sewaktu-waktu yang dapat mereka alami. Kondisi ini semakin riskan ketika perlindungan terhadap kaum marginal di negara kita juga lemah, seperti di tuliskan oleh Nadia Ayu, wanita korban kekerasan seksual masih sangat beresiko di salahkan secara Hukum, penyandang disabilitas sering mendapat perlakuan diskriminasi, dan bahaya yang mengintai kaum miskin di perkotaan karena adanya ponsel ilegal. $^{3}$

Ada beberapa kekerasan dan tindakan diskriminasi yang di alami kaum marginal pada beberapa waktu terakhir ini, antara lain: dugaan kekerasan terhadap buruh perempuan di PT Taekwang Industrial, Kabupaten Subang yang dilakukan oleh seorang tenaga kerja asing (TKA)

${ }^{1}$ R. R. Samudra and D. Setyonaluri, "Studi Kerentanan Kelompok Marjinal di Masa Pandemi COVID-19," Depok, Jawa Barat, 2020

${ }^{2}$ A. Sidqi, "Survei Lean On: Kelompok Marginal Rentan di Tengah Pandemi," Gatra.com, Jakarta, p. 1, 2021

${ }^{3}$ N. Ayu, "Lemahnya Perlindungan Hukum Bagi Kaum Marjinal di Indonesia," ketikunpad, 2021 
dengan mengayunkan keras kaki kirinya ke arah perempuan yang sudah bersimpuh di lantai. ${ }^{4}$ Selain itu kekerasan kepada kaum marginal khususnya pada penderita disabilitas juga marak terjadi, berdasarkan data Komisi Nasional atau Komnas Perempuan mencatat bahwa propinsi DKI jakarta adalah propinsi dengan kasus kekerasan terhadap perempuan disabilitas tertinggi di Indonesia, kemudian diikuti oleh propinsi Yogyakarta. ${ }^{5}$ Diskrimasi terhadap kaum marginal berdasarkan sebuah penelitian yang diungkapkan dalam sebuah media online juga menyebutkan masih marak terjadi, antara lain layanan terhadap pasien miskin dengan jaminan kesehatan sosial dilayani terakhir mulai dari loket pendaftaran hingga layanan perawat dan dokter seringkali di pimpong. ${ }^{6}$

Berdasarkan latar belakang yang telah penulis kemukakan, terdapat beberapa rumusan masalah antara lain: apakah kaum marginal itu? Apa pendapat orang Kristen itu sendiri dengan kaum marginal? Apa peran gereja dalam menyikapi kekerasan dan diskriminasi kepada kaum marginal? Mampukah orang Kristen mengaplikasin spiritualitas mereka dalam mengaplikan HAM kepada kaum marginal? Maka dalam pembahasan ini, penulis memfokuskan pembahasan kepada bagaiman spiritualitas Kristen menjadi dasar mengaplikasikan HAM kepada kaum marginal.

\section{METODE}

Pembahasan dalam artikel ini, penulis menggunakan metode kualitatif, yaitu penelitian berkaitan dengan data dan menganilsis data yang bersifat naratif, sehingga informasi yang mendalam tentang isu atau masalah dapat dipecahkan. ${ }^{7}$ Teknik yang digunakan penulis adalah dengan literature review atau studi pustaka, hal ini dikarenakan artikel ini merupakan kajian teoritis. Penulis memperoleh data primer dari literature research, data sekundernya penulis dapatkan dari buku, jurnal, majalah online, surat khabar online dan halaman web yang ada di internet. Langkah awal yang penulis lakukan adalah dengan menentukan masalah atau fenomena ayang ada, kemudian menggali data dari sumber-sumber, membuat evaluasi kemudian menemukan dan mengembangkan teori melalui tinjauan pustaka.

\section{Hasil dan Pembahasan}

\section{Definisi Kaum Marginal}

Kata Marginal berasal dari kata bahasa Inggris "Marginal" yang berarti dampak yang sangat kecil atau jumlah. Marginal sering diartikan sebagai kelompok masyarakat yang jumlahnya sangat kecil atau dapat diartikan kelompok masyarakat yang kurang sejahtera. Mereka adalah kelompok yang sering terpinggirkan atau terkucilkan dari kehidupan masyarakat, biasanya mereka adalah orang tidak berpendidikan, kumuh, miskin dan tidak tertib. ${ }^{8}$

\footnotetext{
${ }^{4}$ CNN, "Ramai-ramai Kecam Kekerasan terhadap Buruh Perempuan Subang Baca artikel CNN Indonesia 'Ramai-ramai Kecam Kekerasan terhadap Buruh Perempuan Subang' selengkapnya di sini: https://www.cnnindonesia.com/nasional/20210309174252-20-615659/ramai-ramai-kecam-kek," p. 2, 2021

${ }^{5}$ C. Nilawaty and R. Kustiani, "Kasus Kekerasan Terhadap Perempuan Disabilitas Tertinggi di DKI Jakarta," Majalah Tempo, jakarta, p. 2, 2020.

${ }^{6}$ L. Kus Anna, "Pasien Miskin Mendapat Layanan Diskriminatif Artikel ini telah tayang di Kompas.com dengan judul 'Pasien Miskin Mendapat Layanan Diskriminatif', Klik untuk baca:

https://nasional.kompas.com/read/2012/09/28/11094194/pasien.miskin.mendapat.layanan.diskrimin," Kompas.com, p. 1, Sep. 28, 2012.
}

${ }^{7}$ Sugiyono, Metode Penelitian Kualitatif, 1st ed. Bandung, 2017

${ }^{8}$ I. S. P. Fahrudin, "Kaum Marjinal Tanggungjawab Siapa?," blok Tuban, Tuban, 2018. 
Ada juga yang memberikan definisi kaum Marginal sebagai suatu kelompok warga yang mempunyai keterbatasan akses terhadap berbagai aspek atau bidang-bidang yang dikelolah oleh pemerintah ataupu swasta. Pada umumnya kaum marginal ini mempunyai posisi atau status yang paling rendah pada rakyat. Secara umum mereka yang tergolong masyarakat marginal ialah orang miskin, gelandangan, pengemis, anak jalanan, para penyandang cacat, warga tradisional, serta lain sebaginnya. Mereka terpinggirkan karena tekanan ekonomi, sosial, politik serta termasuk kebijakan pemerintah yg tidak berpihak. Fenomena yang dihadapi warga kini adalah bahwa masyarakat marginal merupakan warga yang identik dengan kaum buruh rendahan, orang yg tinggal dipemukiman kumuh, rakyat desa juga warga kota yang tertinggal karena faktor sumber daya yang tidak mendukung. ${ }^{9}$

Kekerasan kepada kaum marginal ada yang ditunjukan dalam bentuk kekerasan fisik misalnya memukul, menendang, menampar bahkan beberapa kasus penganiayaan kepada buruh, Asisten Rumah Tangga dan penyandang disabilitas sudah di titik kritis yaitu penganiayaan, contohnya dengan mengurung di gudang, menyekap, menyiram air panas dan bahkan sampai melukai. Tetapi tidak sedikit juga kaum marginal yang mengalami kekerasan secara psikis, misalnya: kata-kata kasar dengan sebutan bodoh, miskin, bau, kotor, wana (pribumi) dan katakata lainnya yang tentunya memberi luka secara psikis pada mereka. Termasuk sikap dan perilaku dengan gestur tidak suka, misalnya: memandang sebelah mata, memandang sinis, membuang muka, menutup hidung ketika berdekatan atau bercakap-cakap dan juga menghindar ketika di dekati kaum marginal. Perlakuan diskriminasi juga kerap dialamai kaum marginal baik dalam memperoleh pendidikan, layanan publik misalnya pelayanan kesehatan di rumah sakit, posyandu, vaksinasi, juga dalam layanan pemerintahan.

Gereja dan warga gereja tanpa disadari juga kerap memperlakukan kaum marginal tidak semestinya, masih saja warga gereja yang menilai rendah sebuah suku atau kelompok masyarakat walaupun sudah percaya Tuhan Yesus dan satu gereja, masih ada warga gereja yang tidak mau duduk bersama dengan kaum marginal, tidak mau menyapa, dan bersalaman dengan mereka, membuat kelompok sendiri yang satu suku dan satu level dengan mereka, menutup diri dengan kelompok kaum marginal, menyuruh kaum marginal untuk mengerjakan tugastugas gereja yang kotor misalnya menyapu, mengepel gereja, bersih-bersih, sementara mereka sendiri mengerjakan bagian-bagian pelayanan yang bersih dan tampak di umum misalnya Whorship Leader (MC), Singer, Penerima Tamu, dan Pengkhotbah. Bahkan ada juga kaum marginal yang tidak diberi hak bicara dalam sebuah rapat gereja, tidak diberi kesempatan menduduki jabatan penting dalam gereja.

Semua hal-hal ini menjadi sebuah potret mengenai kekerasan dan diskriminasi kepada kaum marginal yang masih terjadi di masyarakat dan juga di dalam gereja, walaupun taraf atau skala kekerasan atau diskrimasi itu sendiri ada yang berat dan ada yang masih ringan, tetapi kekerasan adalah kekerasan, diskriminasi tetaplah sebuah diskriminasi yang harus dicegah dan di atasi sedini mungkin.

\section{Kaum Marginal dan Hak Asasi Manusia}

Perlindungan terhadap kaum marginal sebagai manusia yang bermartabat sebenarnya sudah sejak dulu telah ada, bahkan sejak manusia itu ada di muka bumi. Perlindungan mengenai hak asasi manusia di Indonesia sebenarnya sudah ada jauh sebelum terbentuknya Deklarasi Hak Asasi Manusia Internasional (The Universal Declaration of Human Rights) pada

\footnotetext{
${ }^{9}$ R. Rahman, "Peran Agama dalam Masyarakat Marginal," Univ. Islam Negeri Alluddin Makassar, vol. 1, p.
} 10, 2019. 
tanggal 10 Desember 1948, yaitu saat peristiwa kemerdekaan negara Indonesia pada tanggal 17 Agustus 1945 yang diikuti dengan diakuinya Pancasila sebagai dasar Negara dan Pembukaan UUD 1945 sebagai hukum dasar tertulis dan menjadi sumber hukum bagi peraturan perundangan yang berlaku termasuk di dalamnya perlindungan terhadap hak-hak manusia termasuk hak kaum marginal.

Hak-hak yang bersifat mendasar dan melekat dengan jati diri manusia secara universal itulah yang dimaksud dengan HAM. Setiap manusia berhak memiliki hak tersebut. Artinya walaupun dalam eksistensi kemanusiaan terjaga, ia juga berkewajiban yang sungguh-sungguh untuk dimengerti, dan dipahami serta bertangungjawab untu mau memeliharanya. ${ }^{10}[10]$ Perlindungan hak-hak asasi manusia termasuk kaum marginal menjadi semakin kuat saat terbentukanya Komisi Nasional Hak Asasi Manusia (KOMNAS HAM) pada tahun 1993, yang berfungsi menegakan hak asasi manusia di Indonesia. Kemudian diikuti oleh TAP MPR No XVII/MPR/1998 tantang Hak Asasi Manusia, Piagam HAM Indonesia tahun 1998, dan UndangUndang Nomor 39 tahun 1999 tentang HAM, yang disahkan pada 23 September 1999. ${ }^{11}$

Kendati aturan Hukum dan perundangan telah di sahkan dan diberlakukan, fakta di lapangan menunjukan masih banyak pelanggaran hak-hak asasi manusia terjadi di negara ini, termasuk kekerasan dan diskriminasi terhadap kaum marginal. Survei yang penulis bahas dalam latar belakang jelas menunjukan bahwa kekerasan dan diskriminasi akhir-akhir ini meningkat. Berdasarkan analisa penulis, dengan semakin banyak dan kuatnya Hukum dan peraturan perundangan yang berlaku di Indonesia tidak serta merta persoalan kekerasan dan diskriminasi selesai, tetapi perlunya usaha saling melengkapi dari semua elemen masyarakat untuk berperan aktif menjaga dan mengantisipasi kekerasan dan perlakuan diskriminatif kepada kaum marginal. Pada dasarnya semua manusia mengakui hak yang dimiliki setiap orang, Novalina mengatakan, HAM diakui sebagai hak yang dimiliki setiap orang semata-mata sebab ia insan, terlepas berasal pertaliannya menggunakan agama atau institusi lainnya. ${ }^{12}$

Beberapa kasus kekerasan yang dialami kaum marginal di lapangan lebih di dominasi karena faktor individu atau perseorangan, misalnya oknum salah satu pimpinan atau atasan dalam sebuah perusahaan, bukan disebabkan oleh aturan institusi atau perusahaan itu sendiri. Demikian juga kekerasan dalam Rumah Tangga dan juga pelecehan dan diskriminasi perempuan dan disabilitas di dominasi faktor individu. Hal ini menunjukan bahwa kemampuan setiap individu mengendalikan hasrat dan emosi yang negatif dan destruktif menjadi faktor mendasari pelanggaran HAM kepada kaum marginal. Hal ini upaya merekonstruksi pola kognitif fundamentalis pun perlu dilengkapi dengan metode menelusuri hubungan pelik antara hasrat, emosi, nalar, pilihan moral dan spiritual. sementara cita-cita serta emosi membentuk motivasi, kepekaan moral serta gairah spiritual bisa meradikalkan atau memoderatkan motivasi. ${ }^{13}$

Berpikir rasional sebenarnya dapat membantu manusia untuk mengenali perilaku buruk, keinginan destruktif, dan perasaan emosi yang dapat memicu manusia melakukan kekerasan dan diskriminasi terhadap sesamanya. Bahkan berpikir rasional dapat meningkatkan moralitas seseorang, sehingga mencegah melakukan tindakan yang menyakiti orang lain. Berpikir rasio-

\footnotetext{
${ }^{10}$ M. El Muhtaj, Hak Asasi Manusia dalam Konstitusi Indonesia, Kedua. Jakarta: Kencana, 2017

${ }^{11}$. Bessie, Pendidikan Agama Kristen dan Budi Pekerti Hidup Berdemokrasi, Ketiga. Jakarta: PT. BPK Gunung Mulia, 2021

${ }^{12}$ M. Novalina, "Spiritualitas Orang Kristen Dalam Menghadirkan Kerajaan Allah di Tengah Tantangan Radikalisme," J. Teol. Kontekst. Indones., vol. 1, no. 1, p. 26, Jun. 2020, doi: 10.46445/jtki.v1i1.293.

${ }^{13}$ Ibid.
} 
nal memilki kaitan erat dengan spiritualitas, karena spiritulitas bukan hanya diisi argumen akademik teologi dan filsafat saja tetapi juga nalar. Spiritualitas memang memiliki sudut pandang berbeda-beda tergantung pribadi dan agama seseorang. Intelektualitas merupakan bagian tak terpisahkan dari spiritualitas, tetapi spiritualitas juga digerakan faktor emosi dan imajinasi, kebanyakan agama mengajarkan bahwa latihan spiritual dimulai dengan mengenali gerak emosi, setelah itu bagaimana teknik mengendalikan dan merawat emosi. ${ }^{14}$

Berdasarkan analisis di atas, dapat disimpulkan bahwa memang spiritualitas bukanlah yang mengawali mendorong motivasi manusia untuk melakukan tindakan pelanggaran HAM secara khusus kepada kaum marginal, namun kematangan spiritual atau kadar spiritual baik secara individu maupun publik, dapat meningkatkan kerohanian dan karakter yang sehat. Bagi orang Kristen kemampuan untuk menanggulangi emosi dan hasrat yang membuat seseorang melakukan kekerasan atau diskriminasi yaitu dengan mempelajari Kitab Suci, sehingga dapat mengatur dan menjaga emosi dan perilaku mereka. Memang perlu disadari bahwa, tidak bisa menaruh dan mendasarkan hanya pada spiritualitas semata, tetapi perlu kerja sama juga dengan semua bidang keilmuan lainnya seperti budaya, sosologis, ekonomi dan kebijakan politik yang juga perlu menjadi perhatian dan patut di jalankan.

\section{Spiritualitas Kristen}

Berdasarkan $\mathrm{KBBI}$, Spiritual berhubungan dengan atau bersifat kejiwaan (rohani, batin). ${ }^{15}[13]$ Sidjabat mengatakan, spiritualitas (Latin) atau spirituality (Inggris) berarti keadaan tidak berwujud material dari suatu substansi, atau sebagai atribut dari makhluk spiritual (immateriality of substance, an attributte of spiritual beings). Kata "spiritualitas" berasal dari akar kata spiitus (Latin) atau spirit (Inggris), menunjuk kepada substansi non-material atau makhluk (being) yang substansinya tidak material (Muller, 1985). ${ }^{16}$

Leon McKenzie yang memberikan definisi spiritualitas dalam bukunya "Developmental Spirituality and The Religious Educator" adalah: (1) teknik-teknik meningkatkan pengalaman rohani; (2) tinggi rendahnya kadar kerohanian; (3) aktivitas atau kegiatan kerohanian; (4) sebagai gerakan asketisme, pietisme, dan emosi keagamaan. ${ }^{17}$ Ada juga yang memberi pandangan sipiritualitas adalah kekuatan yang bersumber dari manusia semata untuk menunjukan hidup yang bermakna bagi sesama. ${ }^{18}$

Berdasarkan beberapa pandangan diatas, maka dapat disimpulkan bahwa spiritualitas merupakan sebuah pendorong dari batin manusia untuk menggerakan sebauh perilaku atau tindakan yang berarti bagi sesamanya. Kekuatan atau energi dari dalam yang menggerakan tentunya ada sumbernya, dan sumber tersebut tentunya dipengaruhi oleh setiap individu itu sendiri beriman dan mempercayai siapa? Bagi orang Kristen kekuatan atau energi yang menjadi sumbernya tentunya adalah Tuhan Yesus Kristus yang di wujudkan dengan kehadiran dan karya Roh Kudus di dalam diri orang Kristen. Jadi Roh Kuduslah yang memberikan spiritualitas sejati dalam hidup orang Kristen. Roh kudus inilah yang menggerakan seseorang untuk mampu menampakan karakter, hasrat dan emosi yang baik untuk menjalin hubungan harmonis dengan Allah pemberi hidup dan juga sesamanya.

\footnotetext{
${ }^{14} \mathrm{Ibid}$

15 "Kamus Besar Bahasa Indonesia." https://kbbi.web.id/spiritual.

${ }^{16}$ B. S. Sidjabat, Strategi Pendidikan Kristen, Revisi 199. Yogyakarta: Andi Offset, 1996.

${ }^{17}$ Ibid.

${ }^{18}$ Ibid.
} 


\section{Spiritualitas Kristen sebagai Dasar HAM}

Di dalam Mukadimah Deklarasi Universal tentang Hak Asasi Manusia telah disetujui oleh Resolusi Majelis Umum Perserikatan Bangsa-Bngsa Nomor 217 A (III) tanggal 10 Desember 1948 memuat beberapa pertimbangan-pertimbangan, pada kesempatan ini penulis hanya akan memberikan poin yang paling mendasar saja yaitu ${ }^{19}$ :

1. Menimbang bahwa pengakuan atas martabat yang melekat dan hak-hak yang sama dan tidak terasingkan dari semua anggota keluarga kemanusiaan, keadilan dan perdamaian dunia.

2. Menimbang bahwa mengabaikan dan memandang rendah pada hak-hak asasi manusia telah mengakibatkan perbuatan-perbuatan bengis yang menimbulkan rasa kemarahan dalam hati nurani umat manusia dan bahwa terbentuknya suatu dunia dimana manusia akan mengecap kenikmatan kebebasan berbicara dan agama serta kebebasan dari rasa takut dan kekurangan telah dinyatakan sebagai aspirasi tertinggi dari rakyat jelata.

3. Menimbang bahwa hak-hak manusia perlu di lindungi oleh peraturan hukum supaya orang tidak akan terpaksa memilih pemberontakan sebagai usaha yang terakhir guna menentang kelaliman dan penjajajhan.

Berdasarkan tiga poin penting dari Mukadimah Deklarasi Hak Asasi Manusia ini, maka Hak Asasai Manusia merupakan hak dasar saat manusia dilahirkan sebagai anugerah dari Allah Yang Maha Kuasa, Hak yang melekat pada sesama manusia merupaka hak yang jug tidak boleh dilanggar oleh siapapun, dan hak ini selalu diikuti dengan kewajiban.

Apa yang menjadi inti penting Hak Asasi Manusia memiliki makna dan nilai yang sama dengan iman Kristen, karena manusia adalah ciptaan Allah yang diciptakan serupa dan segambar dengan Allah (Kej. 1:27), Allah sendiri menghembuskan nafas kehidupan ke hdiung manusia sehingga ia hidup (Kej. 2:7) dan sesungguhnya tidak ada seorangpun atau lembaga apapun yang berkuasa membatalkan hak-hak tersebut. Artinya hanya Allah yang berkuasa atas manusia dan tidak ada yang boleh berkuasa selaian Dia. Manusia yang diciptakan serupa dan segambar dengan Allah sesungguhnya itu merupakan pribadi yang utuh dihadapan Allah dan sesamanya. la bertanggung jawab langsung kepada Allah.

Manusia sesungguhnya adalah merupakan ciptaan Allah yang tertinggi dan mulia. la memiliki harkat dan martabat yang sangat tinggi. Jika manusia menghormati hak asasi sesama manusia berarti la menghormati Allah, Penciptanya. Tetapi sebaliknya jika ia melanggar hak asasi manusia berarti ia merampas hak Allah juga sebagai penciptanya.

\section{Nilai-Nilai Spiritualitas Kristen sebagai Dasar HAM antara lain:}

\section{Nilai Menghormati Allah}

Saat Allah mencipta manusia (Kej. 1:26) "Berfirmanlah Allah: "Baiklah kita menjadikan manusia menuurt gambar dan rupa Kita," Hak asasi manusia dengan sendirinya melakat dalam diri manusia ketika Allah menciptakannya, Allah sendiri yang memberi kehidupan dan anugerahNya kepada manusia ciptaanNya (Maz. 22:10; 139:16) Nilai menghormati Allah tercermin dengan bagaimana kita memperlakukan sesamanya. Jika manusia menghormati Allah, niscaya ia juga menghormati sesama, demikian sebaliknya (Amsal 14:31; 17:5). Sikap yang menghargai kehidupan maka ia tidak akan semena-mena terhadap orang lain. Contoh

\footnotetext{
${ }^{19}$ S. Sumaryono et al., Pendidikan Kewarganegaraan, Cetakan ke. Jakarta: PT. Gramedia Putaka Utama, 2008
} 
perilaku yang tidak menghormati Allah dengan memperlakukan kelompok marginal adalah: Ahab yang merampas kebun anggur Nabot (1 Raj. 21:17-29)

\section{Nilai Menghargai Sesama}

Dalam kesepuluh perintah Tuhan, lima di antaranya adalah supaya kita tidak berbuat yang tidak baik kepada sesamanya: jangan membunuh, jangan berzinah, jangan mencuri, jangan berdusta dan jangan mengingini milik sesamamu (Kel. 20:13-17). Spiritualitas Kristen juga mengajarkan supaya tidak melakukan kekerasan dan diskriminasi kepada sesamanya. Imamat 19:13" janganlah engkau memeras sesamamu manusia dan janganlah engkau merampas; janganlah kautahan upah seorang pekerja harian sampai besok harinya" Sikap Spiritualitas supaya kita menghargai sesama manusia. Sikap menghargai dan menghormati orang lain sesungguhnya wujud ketaatan kepada Allah, Sang Pencipta. Tuhan Yesus juga bersikap baik dan adil kepada semua orang. Ia bersikap adil dan menghormati orang Samaria, walaupun sudah sejak lama orang Yahudi memiliki hubungan tidak baik dengan orang Samaria (Yoh. 4:1-42), la bersikap baik kepada Zakheus walau orang-orang mencibir karena ia seorang pemungut cukai (Luk. 19:10), la bersikap adil kepada perwira di Kapernaum walau tidak sebangsa denganNya (Mat. 8:5-13). la bersikap adil kepada Maria, Martha, Yairus, dan juga kepada janda di Nain.

\section{Nilai Keadilan}

Semua manusia dalam pemandangan Allah adalah sama tanpa ada perbedaan apapun. Hal ini berlaku secara universal, dimana saja dan kapan saja, dalam keadaan suka maupun duka. Maka dari hal itu manusia harus memiliki nilai keadilan. Semua manusia memiliki kewajiban sama baik kepada diri sendiri, menghargai diri sendiri dan juga sesama. Nilai keadilan ini menuntut tanggung jawab untuk saling menerima dan menghargai perbedaan, tanpa memandang bulu. Perintah Allah untuk melakukan dan hidup dalam keadilan sangat jelas, Ul. 16:19-20, Maz. 117:7; Ams. 8:20; 16:8; 21:3; 21:15; Mat. 23:23; 2 Kor. 6:7; Ef. 5:9; 6:14; 1 Tim. 6:11; 2 Tim 2:22

\section{Nilai Kasih}

Sesungguhnya Allah menciptakan manusia sebagai ciptaan yang paling mulia dan derajat yang tinggi dibanding ciptaan lain. Walaupun manusia telah jatuh dalam dosa, kasih Allah tidak berubah, la mengorbankan Anaknya yang terkasih untuk menebus dosa manusia. Kasih Allah membenarkan, memperbaharui dan memberi kehidupan baru, la mengembalikan manusia kepada posisi semula. Kasih Allah mengampuni dan menyelamatkan. Spiritualitas Kristen dengan nilai kasih mendasari HAM supaya dapat menghormati dan menghargai orang lain dengan tulus. Kasih Allah yang menggerakan sesuatu yang mustahil yaitu untuk mengasihi sesamanya. Im. 19:18; Mat. 5:43; Mat. 19:19; Mat. 23:39; Rom. 13:9; Gal. 5:14; Yak. 2:8. Contoh keteladanan kasih Yesus: la mengasihi perempuan yang kedapatan berzinah (Yoh. 8:111), la mengasihi Pengemis Bartimeus (Mar. 10:46-52).

\section{KeSIMPULAN}

Spiritualitas Kristen yang di hadirkan dalam masyarakat, diharapkan mampu sebagai wujud mengaplikasikan HAM kepada kaum merginal di Indonesia. Spiritalitas Kristen yang mendasari HAM haruslah mampu menjadikan orang Kristen saksi dalam menghargai sesama, berlaku adil dan mengasihi kaum marginal. Spirituaitas Kristen wajib menyentuh gereja, keluarga dan juga sekolah, karena pengajaran di tempat-tempat itulah pembentukan kognitif orang Kristen terwujud. Ini menjadi sebuah tindakan preventif warga gereja terjebak pada perilaku 
kekerasan dan diskriminasi kepada kaum marginal. Semua elemen masyarakat orang Kristen perlu memberi perhatian pada pembentukan spiritual Kristen, supaya dapat menampilkan karakter murid Kristus yang dapat menerima orang lain, menghargai sesama walau mereka adalah orang-orang terpinggirkan, menunjuka keadilan tanpa melihat perbedaan suku, status sosial dan cacat fisik. Pengajaran, bimbingan dan diskusi serta dialog yang intens dan berkualitas perlu terus diusahakan baik di lingkungan gereja, keluarga dan juga lingkungan sekolah. Penelitian ini di harapkan menjadi usaha atau usulan untuk mengaplikasikan HAM kepada kaum marginal yang ada di sekita kita.

\section{REFERENSI}

A. Sidqi, "Survei Lean On: Kelompok Marginal Rentan di Tengah Pandemi," Gatra.com, Jakarta, 2021.

B. S. Sidjabat, Strategi Pendidikan Kristen, Revisi 199. Yogyakarta: Andi Offset, 1996.

CNN, "Ramai-ramai Kecam Kekerasan terhadap Buruh Perempuan Subang Baca artikel CNN Indonesia 'Ramai-ramai Kecam Kekerasan terhadap Buruh Perempuan Subang' selengkapnya di sini: https://www.cnnindonesia.com/nasional/20210309174252-20615659/ramai-ramai-kecam-kek," 2021.

C. . Nilawaty and R. Kustiani, "Kasus Kekerasan Terhadap Perempuan Disabilitas Tertinggi di DKI Jakarta," Majalah Tempo, jakarta, 2020.

I. S. P. Fahrudin, "Kaum Marjinal Tanggungjawab Siapa?," blok Tuban, Tuban, 2018.

"Kamus Besar Bahasa Indonesia." https://kbbi.web.id/spiritual.

L. Kus Anna, "Pasien Miskin Mendapat Layanan Diskriminatif Artikel ini telah tayang di Kompas.com dengan judul 'Pasien Miskin Mendapat Layanan Diskriminatif', Klik untuk baca:

https://nasional.kompas.com/read/2012/09/28/11094194/pasien.miskin.mendapat.layana n.diskrimin," Kompas.com, p. 1, Sep. 28, 2012.

M. Novalina, "Spiritualitas Orang Kristen Dalam Menghadirkan Kerajaan Allah di Tengah Tantangan Radikalisme," J. Teol. Kontekst. Indones., vol. 1, no. 1, Jun. 2020, doi: 10.46445/jtki.v1i1.293.

M. El Muhtaj, Hak Asasi Manusia dalam Konstitusi Indonesia, Kedua. Jakarta: Kencana, 2017.

N. Ayu, "Lemahnya Perlindungan Hukum Bagi Kaum Marjinal di Indonesia," ketikunpad, 2021.

R. Rahman, "Peran Agama dalam Masyarakat Marginal," Univ. Islam Negeri Alluddin Makassar, vol. 1, 2019.

R. R. Samudra and D. Setyonaluri, "Studi Kerentanan Kelompok Marjinal di Masa Pandemi COVID-19," Depok, Jawa Barat, 2020.

S. Sumaryono et al., Pendidikan Kewarganegaraan, Cetakan ke. Jakarta: PT. Gramedia Putaka Utama, 2008.

Sugiyono, Metode Penelitian Kualitatif, 1st ed. Bandung, 2017.

Y. Bessie, Pendidikan Agama Kristen dan Budi Pekerti Hidup Berdemokrasi, Ketiga. Jakarta: PT. BPK Gunung Mulia, 2021. 